\title{
Fluorescence and Optical Characteristics of Reduced Flavines and Flavoproteins ${ }^{\dagger}$
}

\author{
Sandro Ghisla, Vincent Massey,* Jean-Marc Lhoste, and Stephen G. Mayhew
}

ABSTRACT: The fluorescence and absorption properties of a series of reduced flavoproteins have been measured and compared with the properties of suitable model compounds. Contrary to common belief, a number of reduced flavoproteins have been found to exhibit appreciable fluorescence emission with maxima in the range $500-530 \mathrm{~nm}$. In keeping with common observation, the reduced model flavines are devoid of fluorescence in solution at room temperature, but show marked fluorescence emission in the range 476-512 nm at $77^{\circ} \mathrm{K}$ in rigid glasses. The fluorescence quantum yield of reduced lactate oxidase (emission $\lambda_{\max } 507 \mathrm{~nm}$ ) is increased 4.7 times upon formation of covalent $N_{5}$ adducts and the emission maximum is shifted to $476 \mathrm{~nm}$. In the case of the nonfiuores-

\footnotetext{
$\mathrm{T}_{\mathrm{h}}$
} electronic properties of the isoalloxazine chromophore system, which constitutes the redox active moiety of the flavine coenzymes, have been the object of several thorough theoretical and experimental investigations (Sun et al., 1972; Song, 1971, and literature cited therein). These studies have dealt mainly with the oxidized form of the free and proteinbound flavine as well as with model compounds. A distinctive characteristic of oxidized free flavines is their relatively strong fluorescence (quantum yield $\sim 0.3$; Sun et al., 1972), with an emission maximum typically around $520 \mathrm{~nm}$. The energy and intensity of this emission are dependent on solvent polarity and temperature (Koziol, 1969; Sun el al., 1972; Kotaki et al., 1967), on formation of complexes with a variety of molecules (Weber, 1950; Slifkin, 1971), and on the position and properties of substituents (Ghisla and Hemmerich, 1971; Walker et al., 1972; Sun et al., 1972). Similar effects have been observed with riboflavine, $\mathrm{FMN}$, or $\mathrm{FAD}^{1}$ bound to various apoproteins.

Unfortunately the spectroscopy of reduced fiavines has received far less attention than that of the oxidized flavoquinones. A reason for this could be the absence of wellresolved structure in the near-ultraviolet absorption spectrum and of fluorescence at ambient temperature in any solvent. On the other hand, the nonplanarity of the flavine ring in its reduced forms introduces difficulties in theoretical calculations

† From the Department of Biological Chemistry, The University of Michigan Medical School, Ann Arbor, Michigan 48104, and Fondation Curie, Institut du Radium, Section de Biologie, 91405 Orsay, France. Received September 6, 1973. This work was supported by a research grant from the National Institutes of Health (GM11106) to V. M. and a grant from the Schweizerische Naturforschende Gesellschaft to S. G. This work was presented in part at the 50th Anniversary Meeting of the Japanese Biochemical Society, Nagoya, Japan, Sept 1973.

$\ddagger$ Present address: Laboratorium voor Biochemie, Landbouwhogeschool, Wageningen, The Netherlands.

* Address correspondence to this author at the University of Michigan.

${ }_{1}^{1}$ Abbreviations used are: FAD, flavine adenine dinucleotide; FMN, flavine mononucleotide; $F 1_{o x}$, oxidized flavine chromophore; $F 1_{\text {red, }}$ reduced flavine chromophore (dihydroflavine). cent reduced D-amino acid oxidase, formation of covalent adducts leads to appearance of a fluorescence emission maximal at $520 \mathrm{~nm}$. Among the enzymes investigated the absorption spectra of the reduced forms vary markedly. The chromophore of the reduced flavine was found to be very sensitive to variations of the polarity, $\mathrm{pH}$, or viscosity of the solvent and to substitution. An attempt is made to interpret the absorption and fluorescence emission spectra and to correlate the mentioned effects. Thus valid information about the protein environment at the flavine binding site may be obtained. In particular, in the case of fluorescent-reduced enzymes, the vibrational mobility of the reduced flavocoenzyme is restricted by the protein.

of the spectroscopic data and leaves some uncertainties in their interpretation. It is commonly assumed that all species of reduced alloxazines and isoalloxazines, both free and protein bound, are nonfluorescent under the usual experimental conditions. One exception previously reported involves isoalloxazines in which the (probably) nonfunctional carbonyl group at position $\mathrm{C}_{4}$ is reduced by borohydride, but in this case the system retains its redox properties as well as catalytic activity with the enzymes D- and L-amino acid oxidases (Massey et al., 1968), and can therefore be considered to be a modified oxidized flavine. The other reported case is the adduct of lactate oxidase and $\alpha$-hydroxybutynoic acid, the structure of which has not yet been elucidated in detail but which can be assumed to constitute a modified reduced flavine (Walsh et al., 1972).

During the course of our work, we observed that the reduced forms of several flavoproteins exhibit strikingly different absorption spectra. Surprisingly, the reduced form of lactate oxidase was found to have a fairly strong yellow fluorescence in sharp contrast to its oxidized form which is nonfluorescent. These observations prompted a survey of the spectral characteristics of a number of flavoproteins available to us and a more detailed investigation of the absorption and fluorescence spectroscopy of the reduced flavine chromophore. Some of the limitations imposed by the structureless absorption spectra and the absence of fluorescence with free flavines have been overcome in the present work by using appropriately substituted model compounds which were measured in a rigid glassy solvent at $77^{\circ} \mathrm{K}$. Under these conditions the absorption spectra appeared far better resolved and the fluorescence could be observed allowing an easier identification of the lowest electronic transition.

\section{Experimental Section}

Enzymes. Lactate oxidase was prepared from $M y c o-$ bacterium smegmatis by the method of Lockridge et al. (1972). Glucose oxidase was prepared by the method of Swoboda 
and Massey (1965). Flavodoxins were isolated from Peptostreptococcus elsdenii (Mayhew et al., 1969) and from Clostridium MP (Mayhew, 1971). Butyryl coenzyme A dehydrogenase was isolated from Peptostreptococcus elsdenii (Engel and Massey, 1971). Shethna flavoprotein was a gift from Dr. Helmut Beinert (Shethna et al., 1966), L-Amino acid oxidase was prepared from Crotalus adamanteus venom by the method of Wellner and Meister (1960). D-Amino acid oxidase was prepared from pig kidneys as described by Brumby and Massey (1968). Old yellow enzyme was prepared from brewer's bottom yeast by the method of Matthews and Massey (1969). Oxynitrilase was a gift from Dr. E. Pfeil (Becker and Pfeil, 1966). $p$-Hydroxybenzoate hydroxylase was isolated from Pseudomonas fluorescens by the method of Howell et al. (1972) and lysine monooxygenase by a modification of the method of Takeda et al. (1969). Melilotate hydroxylase was prepared from Pseudomonas sp by the method of Strickland and Massey (1973). Thioredoxin reductase from Escherichia coli (Zanetti and Williams, 1967) and yeast glutathione reductase (Massey and Williams, 1965) were gifts from Dr. C. H. Williams, Jr. Pig heart lipoyl dehydrogenase was prepared by the method of Massey (1966).

Flavine Models. $\mathrm{N}_{3}$-Carboxymethyllumiflavine (lumiflavine 3-acetate) and 3-methyltetraacetylriboflavine were synthesized from lumiflavine and tetraacetylriboflavine according to Hemmerich (1964) and purified by recrystallization.

3-Methyl-4a,5-propano-4a,5-dihydrolumiflacine. To a nitrogen flushed suspension of $0.5 \mathrm{~g}(1.8 \mathrm{mmol})$ of 3-methyllumiflavine (Hemmerich, 1964) and $2.5 \mathrm{~g} \mathrm{(25} \mathrm{mmol)} \mathrm{of} \mathrm{potas-}$ sium carbonate in a mixture of $20 \mathrm{ml}$ of dimethylformamide and $20 \mathrm{ml}$ of water, $0.9 \mathrm{~g}(5 \mathrm{mmol})$ of sodium dithionite was added under stirring. Upon reduction of the lumiflavine (detected by a change in color and partial solubilization of the suspended material), $3.6 \mathrm{~g}$ (18 mmol) of 1,3-dibromopropane was added and the mixture stirred at room temperature. Completion of the reaction is indicated by disappearance of the fluorescence and $450-\mathrm{nm}$ absorption of the oxidized lumiflavine in an acidified and aerated sample of the reaction mixture. The reaction mixture was then poured into $100 \mathrm{ml}$ of cold water and the yellow precipitate was washed thoroughly with dilute acetic acid and water and recrystallized from methanol--water: yield, $180 \mathrm{mg}$ ( $30 \%$ ) of pure product ; mp 188-190\%; nuclear magnetic resonance (nmr) $\left(\mathrm{CDCl}_{3}\right) 6.8$ and $6.7\left(2 \mathrm{H}, \mathrm{C}_{6}\right.$ and $\mathrm{C}_{9}$ protons $), 3.65$ and $3.25\left(6 \mathrm{H}, \mathrm{N}_{3} \mathrm{CH}_{3}\right.$ and $\left.\mathrm{N}_{10} \mathrm{CH}_{3}\right), 2.22\left(6 \mathrm{H}, \mathrm{C}_{7} \mathrm{H}_{3}+\mathrm{C}_{8} \mathrm{CH}_{3}\right)$, and 4.40-1.60 ppm ( $6 \mathrm{H}$, multiplet, protons of propano bridge). The compound is very sensitive to alkaline hydrolysis. Anal. Calcd for $\mathrm{C}_{17} \mathrm{H}_{20}$ $\mathrm{N}_{4} \mathrm{O}_{2}$ (mol wt 312.37): C, 65.37; $\mathrm{H}, 6.45 ; \mathrm{N}, 17.94$. Found: $\mathrm{C}, 65.31 ; \mathrm{H}, 6.30 ; \mathrm{N}, 17.55$.

3-Methyl-5-ethyl-1,5-dihydrolumiflacine was prepared by reduction of 3-methyl-5-ethyllumiflavoquinonium perchlorate (Ghisla et al., 1973) with $\mathrm{H}_{2}-\mathrm{Pt}$ in acetonitrile and then diluted with ethanol for spectroscopic measurements.

3-Methyl-4a-ethoxy-5-ethyl-4a,5-dihydrolumiflavine

is formed directly upon solution of 3-methyl-5-ethyllumiflavoquinonium perchlorate in absolute ethanol. 1,3-Dimethyl1,5-dihydrolumiflavine was a gift from Dr. F. Müller. FMN and FAD were obtained from Sigma and purified by chromatography on DEAE-cellulose (Massey and Swoboda, 1963). All other chemicals were of reagent grade from commercially available sources.

Methods. Absorption spectra were recorded with a Cary Model 17 or 15 spectrophotometer. Fluorescence emission and excitation spectra were recorded at room temperature with the ratio-recording fluorimeter described by Casola et al. (1966). The temperature was kept constant at $25 \pm 0.3^{\circ}$ during the measurements. The lifetime of the emission from reduced lactate oxidase was measured with a TRW fluorescence lifetime fluorimeter, using $0.01 \mathrm{~m}$ imidazole- $\mathrm{HCl}$ buffer (pH 7.0) at ambient temperature. The reduction of the flavine chromophore was performed with the agents listed in Table I under anaerobic conditions in "Thunberg"-type cuvets. Catalytic reduction of the model flavines was carried out with $\mathrm{H}_{2}-\mathrm{Pd}$ or $\mathrm{H}_{2}-\mathrm{Pt}$ on charcoal in a vessel separated from the cuvet by a sintered glass filter. Upon completion of reduction, which can be monitored by the disappearance of the fluorescence, the reduced flavine was sucked anaerobically into the cuvet by application of vacuum. The cuvet cells had dimensions of $10 \mathrm{~mm}$ in the emission path and of $3 \mathrm{~mm}$ in the excitation path for most measurements of flavoproteins.

The measurements at $77^{\circ} \mathrm{K}$ were carried out essentially as described by Eley et al. (1970). The flavine models $\left(\sim 10^{-5}\right.$ $\mathrm{M}$ ), dissolved in absolute ethanol, were measured in 4-mm o.d. quartz tubes.

The reductions were carried out with $\mathrm{Pt}-$ or $\mathrm{Pd}-\mathrm{H}_{2}$ and monitored by disappearance of the absorption and fluorescence of the oxidized species at $295^{\circ} \mathrm{K}$. The tubes were then sealed under vacuum. As the extinction coefficients refer to the room temperature spectra they must be corrected for solvent contraction at $77^{\circ} \mathrm{K}$.

The flavoenzymes were dissolved in the most suitable buffer systems as given in the literature to yield concentrations of $10^{-5}-3 \times 10^{-5} \mathrm{M}$. Fluorescence intensities relative to $N_{3^{-}}$ carboxymethyllumiflavine $\left(5 \times 10^{-7}-4 \times 10^{-6} \mathrm{M}\right)$ were measured in the same cell under the same experimental conditions. This reference compound was used because of its stability against photodecomposition. At $\lambda_{\mathrm{exc}} 450 \mathrm{~nm}$ and $\lambda_{\mathrm{em} \text { iss }} 520$ $\mathrm{nm}$ it has a quantum yield of $134 \%$ compared to FMN (both compounds are $10^{-6} \mathrm{M}$ in $0.05 \mathrm{M}$ phosphate buffer at $\mathrm{pH} 6$ at $26^{\circ}$ ). The emission intensity of the flavoproteins was measured at the $\lambda_{\max }$ of the emission. The excitation wavelength was chosen at the absorption $\lambda_{\max }$ in the $450-\mathrm{nm}$ region for the oxidized flavoproteins and at the absorption $\lambda_{\max }$ in the $350-\mathrm{nm}$ region for the reduced flavoproteins ( $c f$. Table I). The relative intensities of the protein emission spectra are not corrected for possible self-absorption and for quantum yields and are reported for comparative purposes only.

\section{Results and Discussion}

Spectroscopy of Reduced Flavines in Solution. The $2 \mathrm{e}^{-}$ reduction of $F 1_{o x}$ can lead to several forms of $F 1_{\text {reul }}$, which can be stabilized by appropriate substitution. The chemistry of these different isomeric classes has been reviewed elsewhere (Ghisla et al., 1973). In the present work only the 1,5and 4a,5-dihydroflavines, which have been recognized as biologically relevant, will be discussed.

Unsubstituted 1,5-Dihydroflavines. The absorption spectrum of nonsubstituted 1,5-dihydroflavines is characterized by a poorly structured line shape in the near-ultraviolet (uv) and visible range which is rather sensitive to the nature of the solvent. In general, in nonpolar and aprotic solvents (at room temperature) a better resolution is observed (Figures 1-3). In ethanol at $77^{\circ} \mathrm{K}$, which forms a clear glass, this weakly absorbing region clearly appears to consist of three different electronic transitions having their maximum probability at 404, 340, and $296 \mathrm{~nm}$, respectively (Figure 3). In this rigid solvent a weak fluorescence, the excitation spectrum of which is identical with the absorption spectrum, is observed with a maximum intensity at $495 \mathrm{~nm}$. This fluorescence is the mirror 
TABLE I: Absorption and Fluorescence Characteristics of Flavoproteins. ${ }^{a}$

\begin{tabular}{|c|c|c|c|c|c|c|c|c|c|c|c|}
\hline \multirow[b]{3}{*}{ Enzyme } & \multirow[b]{3}{*}{ Coenzyme } & \multicolumn{4}{|c|}{ Oxidized State $\left(\mathrm{F} 1_{\mathrm{ox}}\right)$} & \multicolumn{6}{|c|}{ Reduced State $\left(1,5-\mathrm{H}_{2} \mathrm{~F} 1_{\text {red }}\right)$} \\
\hline & & & \multicolumn{2}{|c|}{ Fluorescence } & \multicolumn{3}{|c|}{ Absorption } & \multicolumn{2}{|c|}{ Fluorescence } & \multirow[b]{2}{*}{ Reduction Method } \\
\hline & & $\begin{array}{l}\lambda_{\max } \\
(\mathrm{nm})\end{array}$ & $\begin{array}{c}\epsilon\left(10^{3}\right. \\
\mathrm{M}^{-1} \\
\left.\mathrm{~cm}^{-1}\right)\end{array}$ & $\begin{array}{l}\lambda_{\max } \\
(\mathrm{nm})\end{array}$ & $\begin{array}{l}\text { Rel } \\
\text { Inten } \\
(\% \text { of } \\
\text { FMN) }\end{array}$ & $\begin{array}{l}\lambda_{\max } \\
(\mathrm{nm})\end{array}$ & $\begin{array}{l}\epsilon\left(10^{3}\right. \\
\mathrm{M}^{-1} \\
\left.\mathrm{~cm}^{-1}\right)\end{array}$ & $\begin{array}{l}\text { Spectral } \\
\text { Type }^{b}\end{array}$ & $\begin{array}{l}\lambda_{\max } \\
(\mathrm{nm})\end{array}$ & $\begin{array}{l}\text { Rel } \\
\text { Inten } \\
(\% \text { of } \\
\text { FMN })\end{array}$ & \\
\hline Lactate oxidase & FMN & $\begin{array}{l}460 \\
373\end{array}$ & 11.3 & - & - & 360 & 4.8 & 4 & 507 & 7.0 & $\begin{array}{l}\mathrm{NaBH}_{4} \text {, substrate, } \\
\mathrm{Na}_{2} \mathrm{~S}_{2} \mathrm{O}_{4}\end{array}$ \\
\hline $\begin{array}{l}\text { Lactate oxidase (red) } \\
\mathrm{N}_{5} \mathrm{CH}_{2} \mathrm{COOH} \\
\text { adduct }^{c}\end{array}$ & FMN & & & & & 365 & 5.0 & 4 & 476 & 34 & $\begin{array}{c}\mathrm{CH}_{3} \mathrm{CH}(\mathrm{OH}) \mathrm{COOH}- \\
\mathrm{BrCH}_{2} \mathrm{COOH}\end{array}$ \\
\hline Glucose oxidase & FAD & $\begin{array}{l}452 \\
383\end{array}$ & $\begin{array}{l}14.1 \\
13.3\end{array}$ & - & - & 355 & 6.2 & 4 & - & - & $\mathrm{NaBH}_{4}$ \\
\hline $\begin{array}{l}\text { D-Amino acid } \\
\text { oxidase }\end{array}$ & FAD & $\begin{array}{l}455 \\
380\end{array}$ & $\begin{array}{r}11.3 \\
9.7\end{array}$ & 530 & 1.5 & $\begin{array}{l}415 \mathrm{~s} \\
355\end{array}$ & $\begin{array}{l}2.9 \\
4.1\end{array}$ & $2 n$ & - & - & $\begin{array}{l}\text { Substrate, } \mathrm{Na}_{2} \mathrm{~S}_{2} \mathrm{O}_{4} \text {, } \\
\text { EDTA- } h v\end{array}$ \\
\hline $\begin{array}{l}\text { D-Amino acid } \\
\text { oxidase (red) } \\
\mathrm{C}_{4 \mathrm{~B}} \mathrm{CH}_{2} \mathrm{C}_{6} \mathrm{H}_{5} \\
\text { adduct }^{c}\end{array}$ & FAD & & & & & $\begin{array}{l}365 \\
320 s\end{array}$ & $\begin{array}{l}5.8 \\
7.4\end{array}$ & 5 & 520 & 3.9 & $\mathrm{C}_{6} \mathrm{H}_{5} \mathrm{CH}_{2} \mathrm{COOH}-h \nu$ \\
\hline $\begin{array}{l}\text { L-Amino acid } \\
\text { oxidase }\end{array}$ & FAD & $\begin{array}{l}460 \\
383\end{array}$ & 11.3 & - & - & $\begin{array}{l}450 \mathrm{~s} \\
400 \mathrm{~s}\end{array}$ & $\begin{array}{l}2.5 \\
4.5\end{array}$ & $2 n$ & 520 & 3.2 & $\mathrm{Na}_{2} \mathrm{~S}_{2} \mathrm{O}_{4}$, substrate \\
\hline $\begin{array}{l}\text { L-Lysine } \\
\text { monooxygenase }\end{array}$ & FAD & $\begin{array}{l}462 \\
385\end{array}$ & $\begin{array}{l}11.2 \\
11.2\end{array}$ & - & - & $\begin{array}{l}410 \mathrm{~s} \\
350\end{array}$ & $\begin{array}{l}2.8 \\
5.5\end{array}$ & $2 \mathrm{a}$ & 512 & 2.1 & Lysine, $\mathrm{Na}_{2} \mathrm{~S}_{2} \mathrm{O}_{4}$ \\
\hline $\begin{array}{l}\text { Melilotate } \\
\text { hydroxylase }\end{array}$ & FAD & $\begin{array}{l}454 \\
384\end{array}$ & $\begin{array}{l}11.3 \\
10.3\end{array}$ & 530 & 1.2 & $\begin{array}{l}410 \\
350\end{array}$ & $\begin{array}{l}2.5 \\
5.1\end{array}$ & $2 n$ & - & - & EDTA- $h \nu$ \\
\hline $\begin{array}{l}p \text {-Hydroxybenzoate } \\
\text { hydroxylase }\end{array}$ & FAD & $\begin{array}{l}450 \\
374\end{array}$ & 11.3 & 525 & 1.2 & $\begin{array}{l}420 \\
350\end{array}$ & $\begin{array}{l}2.1 \\
5.1\end{array}$ & $2 n$ & - & - & EDTA- $h \nu$ \\
\hline Oxynitrilase & FAD & $\begin{array}{l}460 \\
390\end{array}$ & $\begin{array}{l}11.2 \\
12.4\end{array}$ & - & - & 345 & 5.0 & 4 & 500 & 2.4 & $\mathrm{Na}_{2} \mathrm{~S}_{2} \mathrm{O}_{4}$ \\
\hline $\begin{array}{l}\text { Lipoic acid } \\
\text { dehydrogenase }\end{array}$ & FAD & $\begin{array}{l}455 \\
365 \\
355\end{array}$ & $\begin{array}{r}11.3 \\
9.2 \\
9.1\end{array}$ & 520 & 45 & 360 & 3.5 & 4 & - & - & $\mathrm{Na}_{2} \mathrm{~S}_{2} \mathrm{O}_{4}$ \\
\hline $\begin{array}{l}\text { Glutathione } \\
\text { reductase }\end{array}$ & FAD & $\begin{array}{l}460 \\
370\end{array}$ & $\begin{array}{l}11.3 \\
10.4\end{array}$ & - & - & $d$ & $d$ & & - & - & $\mathrm{Na}_{2} \mathrm{~S}_{2} \mathrm{O}_{4}$ \\
\hline $\begin{array}{l}\text { Thioredoxin } \\
\text { reductase }\end{array}$ & FAD & $\begin{array}{l}480 \mathrm{~s} \\
457 \\
380\end{array}$ & $\begin{array}{r}9.3 \\
11.3 \\
11.7\end{array}$ & 520 & 15.5 & $\begin{array}{l}425 \\
320\end{array}$ & $\begin{array}{l}2.4 \\
9.0\end{array}$ & $3 n, 1 \mathrm{t}$ & - & - & $\mathrm{Na}_{2} \mathrm{~S}_{2} \mathrm{O}_{4}, \mathrm{NaBH}_{4}$ \\
\hline $\begin{array}{l}\text { Butyryl-CoA } \\
\text { dehydrogenase }\end{array}$ & FAD & $\begin{array}{l}448 \\
376\end{array}$ & $\begin{array}{r}10.6 \\
8.2\end{array}$ & 530 & 5.5 & $370 \mathrm{~s}$ & 3.4 & $1 \mathrm{a}$ & 520 & 0.8 & $\mathrm{Na}_{2} \mathrm{~S}_{2} \mathrm{O}_{4}$ \\
\hline $\begin{array}{l}\text { Flavodoxin } \\
\qquad(P . \text { elsdenii })\end{array}$ & FMN & $\begin{array}{l}447 \\
378\end{array}$ & $\begin{array}{l}10.6 \\
9.1\end{array}$ & - & - & $\begin{array}{l}450 \mathrm{~s} \\
365 \\
313\end{array}$ & $\begin{array}{l}1.7 \\
5.5 \\
9.5\end{array}$ & $3 a, 1 t$ & 530 & 0.9 & $\mathrm{Na}_{2} \mathrm{~S}_{2} \mathrm{O}_{4}$ \\
\hline $\begin{array}{l}\text { Flavodoxin } \\
\quad(\text { Clostridium } M P)\end{array}$ & FMN & $\begin{array}{l}447 \\
378\end{array}$ & $\begin{array}{l}10.6 \\
9.1\end{array}$ & - & - & $\begin{array}{l}450 \mathrm{~s} \\
367 \\
315\end{array}$ & $\begin{array}{l}1.5 \\
5.25 \\
8.3\end{array}$ & $3 a, 1 t$ & 530 & 0.75 & $\mathrm{Na}_{2} \mathrm{~S}_{2} \mathrm{O}_{4}$ \\
\hline $\begin{array}{l}\text { "Shetna } \\
\text { flavoprotein" }\end{array}$ & FMN & $\begin{array}{l}452 \\
372\end{array}$ & $\begin{array}{r}10.6 \\
9.6\end{array}$ & - & - & $d$ & $d$ & & - & - & $\mathrm{Na}_{2} \mathrm{~S}_{2} \mathrm{O}_{4}$ \\
\hline $\begin{array}{l}\text { "Old yellow } \\
\text { enzyme" }\end{array}$ & FMN & $\begin{array}{l}462 \\
380\end{array}$ & $\begin{array}{l}10.6 \\
10.6\end{array}$ & 530 & 3.6 & 340 & 4.7 & 4 & - & - & $\mathrm{Na}_{2} \mathrm{~S}_{2} \mathrm{O}_{4}$ \\
\hline
\end{tabular}

${ }^{a}$ For general references concerning the preparation and properties of the listed enzymes and compounds $c f$. the Experimental Section. A dash (-) indicates that no detectable fluorescence was observed; spaces left blank indicate that no information is available or that the form does not exist in the oxidized state. ${ }^{b}$ For the classification see the text. ${ }^{c}$ These adducts were prepared as will be reported elsewhere (S. Ghisla and V. Massey, manuscript in preparation; $c f$. also legend to Figure 9). The structures were attributed based on the characteristic reactivity of the modified coenzymes obtained after release from the protein (Ghisla et al., 1973). In the case of D-amino acid oxidase the photoreaction of $\mathrm{C}_{6} \mathrm{H}_{5} \mathrm{CH}_{2} \mathrm{COO}^{-}$with the oxidized enzyme appears to yield predominantly $\mathrm{C}_{4 \mathrm{a}}$ substitution with some formation of the $\mathrm{N}_{5}$ isomer. ${ }^{d}$ Full reduction of the enzyme was not achieved experimentally.

image, in a wavenumber scale, of the first transition, which is poorly resolved in polar solvents like water, dimethyl- formamide, or ethanol at room temperature, but easily identified in the glassy ethanol spectrum. In toluene (Figure 2) a 


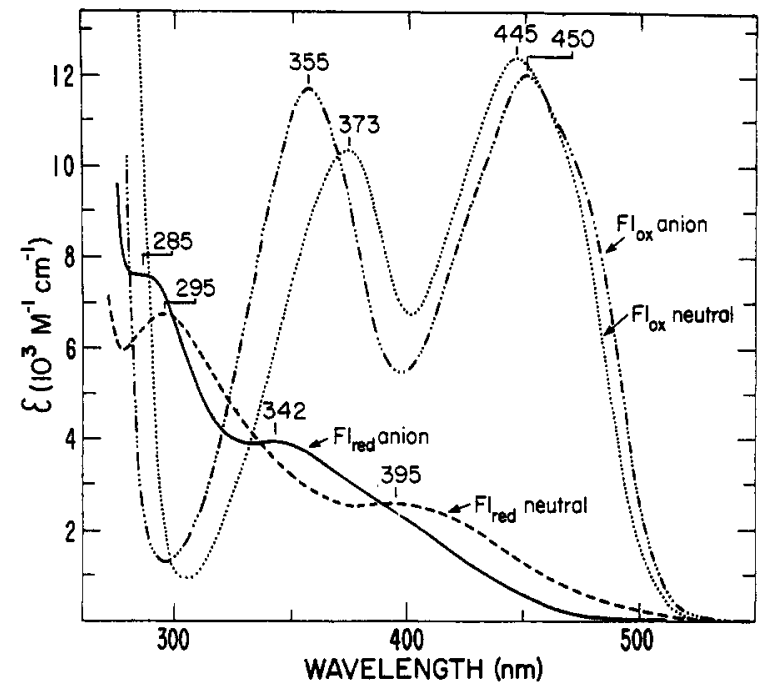

FIGURE 1: Absorption spectra of FMN in aqueous solution in the oxidized and reduced state and in the neutral ( $\mathrm{n}$ ) and anionic state (a): (-...) FMN $\mathrm{FM}_{\text {ox }}$ in $0.033 \mathrm{~N} \mathrm{NaOH} ;(\cdots) \mathrm{FMN}_{\mathrm{ox}}$ at $\mathrm{pH} 5$ in 0.09 M citrate buffer; (-) FMN red at $\mathrm{pH} 8.5$ in $0.1 \mathrm{M}$ pyrophosphate buffer; (--.) FMN ${ }_{\text {red }}$ at pH 5 in $0.09 \mathrm{M}$ citrate buffer. The reductions were achieved by illumination in the presence of EDTA (Frisell et al., 1959).

similar but less pronounced resolution is observed at room temperature, although no fluorescence is detectable.

The flavohydroquinone anion (Figures 1-3), which is formed upon deprotonation at $\mathrm{N}_{1}$, exhibits similar spectra to the neutral species, but with well-defined different characteristics. The relative extent of the long-wavelength absorption of the neutral and anion species appears to vary with the nature of the solvent. In water or toluene a blue shift is apparent for the anion whereas in ethanol or dimethylformamide the spectrum is insensitive to ionization at room temperature. However, in glassy ethanol the better defined first absorption band appears shifted to the red in the anion, as compared to the second and

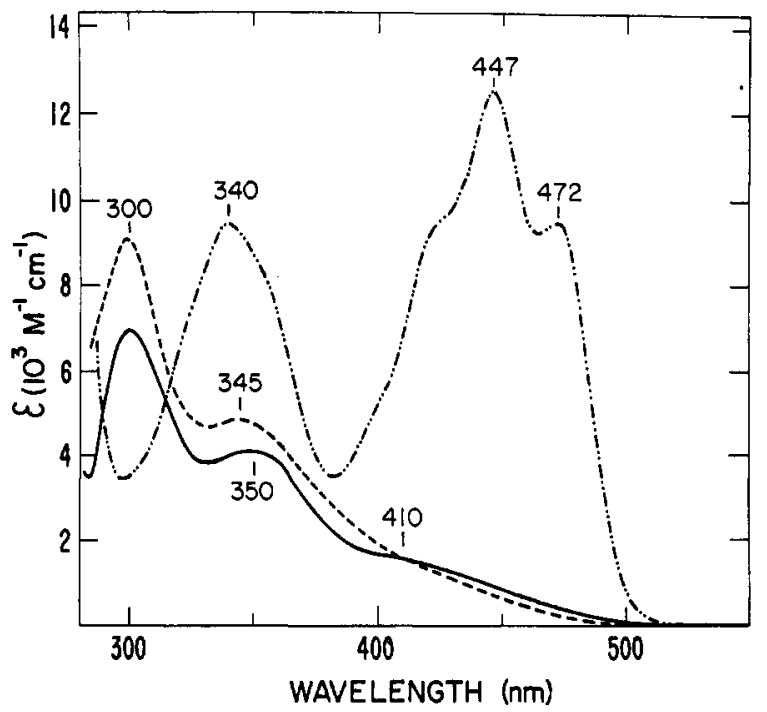

FIGURE 2: Absorption spectra of $N_{3}$-methyltetraacetylriboflavine in toluene in the oxidized and reduced state: $(\cdots)$ the neutral oxidized flavine for comparison; (-) reduced flavine in the neutral state (n); (--) reduced flavine in the presence of $5 \%$ tri-n-butylamine (a). The reduction was carried out with $\mathrm{H}_{2}-\mathrm{Pd}$ as explained in the Experimental Section. (In the presence of a 10 molar excess of benzoic acid the spectrum $(-, n)$ is practically unchanged. Ionization is possibly incomplete even in the presence of $5 \%$ tributylamine.)

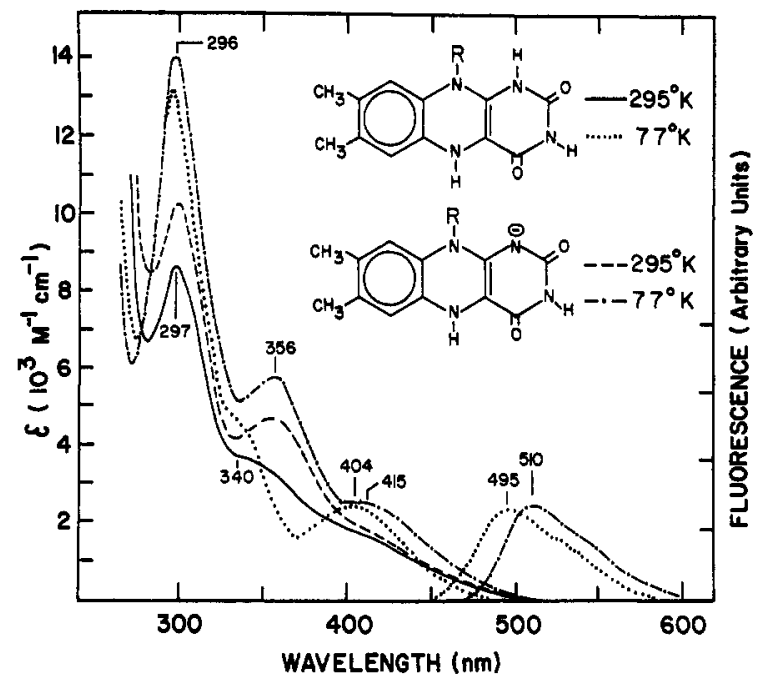

FIGURE 3: Absorption and fluorescence spectra of reduced tetraacetylriboflavine ( $\left.\mathrm{R}=\mathrm{CH}_{2}(\mathrm{CHOAc})_{3} \mathrm{CH}_{2} \mathrm{OAc}\right)$ in ethanol at room $\left(295^{\circ} \mathrm{K}\right)$ and liquid nitrogen $\left(77^{\circ} \mathrm{K}\right)$ temperature. The anion was obtained in the presence of $5 \%$ triethylamine. The extinction coefficients refer to the room temperature spectra. They must be corrected for solvent contraction at $77^{\circ} \mathrm{K}$. The reduction was carried out with $\mathrm{H}_{2}-\mathrm{Pt}$ and the samples were sealed under vacuum in 4-mm o.d. quartz tubes ( $c f$. Experimental Section for further details).

third absorption bands which remain constant (Figure 3 ). This is supported by the $15-\mathrm{nm}$ shift to the red of the low-temperature fluorescence relative to that of the neutral species.

The $F 1_{\text {red }}$ cation is obtained by protonation of the neutral species at $\mathrm{N}_{5}$ at low $\mathrm{pH}$ and does not absorb above $330 \mathrm{~nm}$ (Ghisla et al., 1973). Clearly in this case the conjugation through the central ring is inhibited.

Substituted 1,5-Dihydrolumiflavines. In comparison to the three-banded absorption spectrum of unsubstituted 1,5-dihydroflavines alkyl substitution at $\mathrm{N}_{5}$ appears to result in a single and structureless absorption band above $300 \mathrm{~nm}$ centered around $325-350 \mathrm{~nm}$, depending on the nature of the substituent (Figure 4; Ghisla et al., 1973). $\mathrm{N}_{1}$ mono- (Figure 4) or $\mathbf{N}_{1}, \mathbf{N}_{5}$ disubstitution (not shown) results in a similar effect. However, both the low-temperature absorption spectra

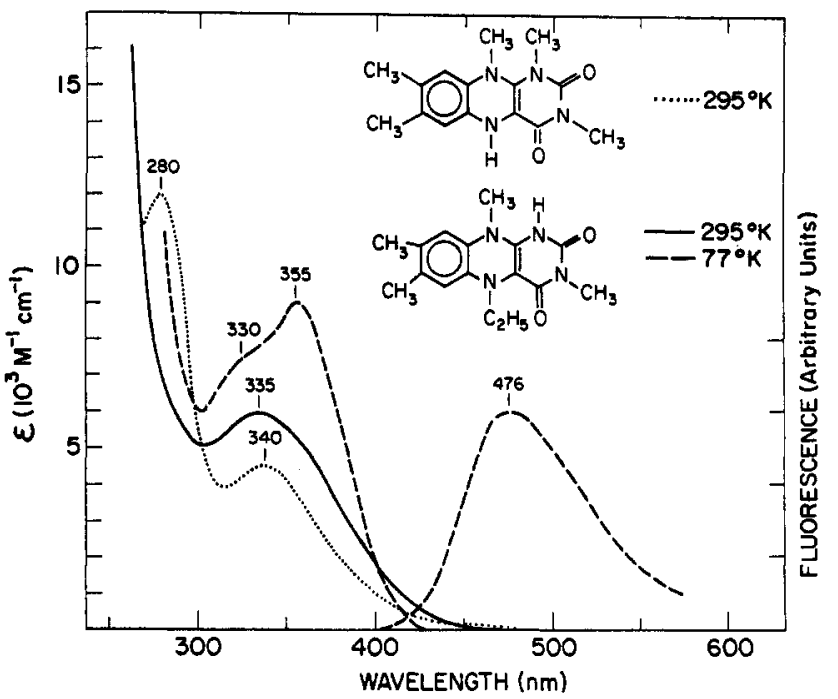

FIGURE 4: Absorption and fluorescence spectra of $\mathbf{N}_{5}$-substituted $\mathrm{Fl}_{\text {red }}$ in ethanol at room $\left(295^{\circ} \mathrm{K}\right)$ and liquid nitrogen temperature $\left(77^{\circ} \mathrm{K}\right.$ ) and of $\mathrm{N}_{1}$-substituted $\mathrm{Fl}_{\text {red }}$ in dioxane at room temperature (cf. Figure 3 and Experimental Section for further details). 


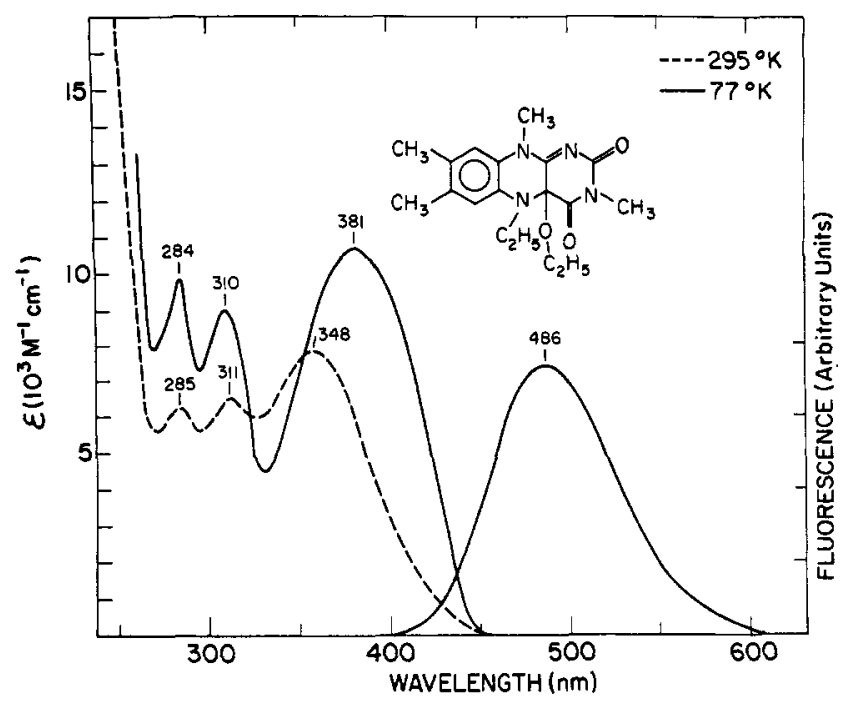

FIGURE 5: Absorption and fluorescence spectra of $4 \mathrm{a}, 5$-disubstituted $\mathrm{Fl}_{\mathrm{red}}$ in ethanol at room $\left(295^{\circ} \mathrm{K}\right)$ and liquid nitrogen temperature $\left(77^{\circ} \mathrm{K}\right)(c f$. Figure 3 and Experimental Section for further details).

and the relatively strong fluorescence observed in ethanol at $77^{\circ} \mathrm{K}$ for the $N_{5}$ substituted compounds indicate that this absorption band consists of two unresolved transitions which must correspond to the electronic transitions of the unsubstituted species, with the first transition being blue shifted upon alkylation. (A similar blue shift of the third transition is also observed.) Furthermore, $N_{5}$ but not $N_{1}$ alkylation appears to intensify the first transition. Thus, this transition contributes to most of the absorption band of $\mathrm{N}_{5}$-substituted compounds, with a maximum around $350 \mathrm{~nm}$ ( $c f$. Figure 4).

Substituted 4a,5-Dihydrolumiflavines. This isomeric form of $F 1_{\text {red }}$ is not the "normal" product of reduction of $F 1_{o x}$, but its derivatives are possible intermediates during flavoprotein catalysis (Hemmerich et al., 1967; Hamilton, 1971; Massey et al., 1969; Walsh et al., 1971; Main et al., 1972). The line shape of its absorption spectrum is similar to that of the $\mathbf{N}_{1}, \mathbf{N}_{5^{-}}$ dihydroflavines, but is even more sensitive to the nature of the substitution (Figures 5 and 6). Very characteristic for this class of compounds is the presence of three absorption bands in the $280-360-\mathrm{nm}$ region, the intensity of which varies considerably depending on the nature of the substituents (Walker et al., 1970; Ghisla et al., 1973). In the case of $C_{4 \mathrm{a}}$-ethoxy- $N_{5}$ ethylflavines these bands are well resolved and can clearly be attributed to three different electronic transitions. In ethanol the lowest energy absorption band is very sensitive to temperature. Although its long-wavelength edge does not shift upon cooling, it rises more steeply and its maximum appears red shifted in the glass at $77^{\circ} \mathrm{K}$. Furthermore, the nonfluorescing compound (at room temperature) exhibits an intense fluorescence at $77^{\circ} \mathrm{K}$, the emission spectrum of which is a better image of the low temperature than of the room temperature absorption spectrum. This suggests that a large change in geometry occurs during the lifetime of the fluorescing state at room temperature, which is prevented in the rigid solvent at low temperature thus resulting in a larger overlap of the absorption and fluorescence spectra. In order to better understand this phenomenon, a $C_{4 a}, N_{5}$-propano $F 1_{\text {red }}$ was synthesized (Figure 6) in which the "bridge" blocks the pyramidal $\mathrm{N}_{5}$ inversion and is expected to induce a much more rigid structure even in fluid solvents. In fact, this flavine was found to be slightly fluorescent at room temperature in ethanol and very strongly fluorescent at $77^{\circ} \mathrm{K}$. On the other hand, it ex-

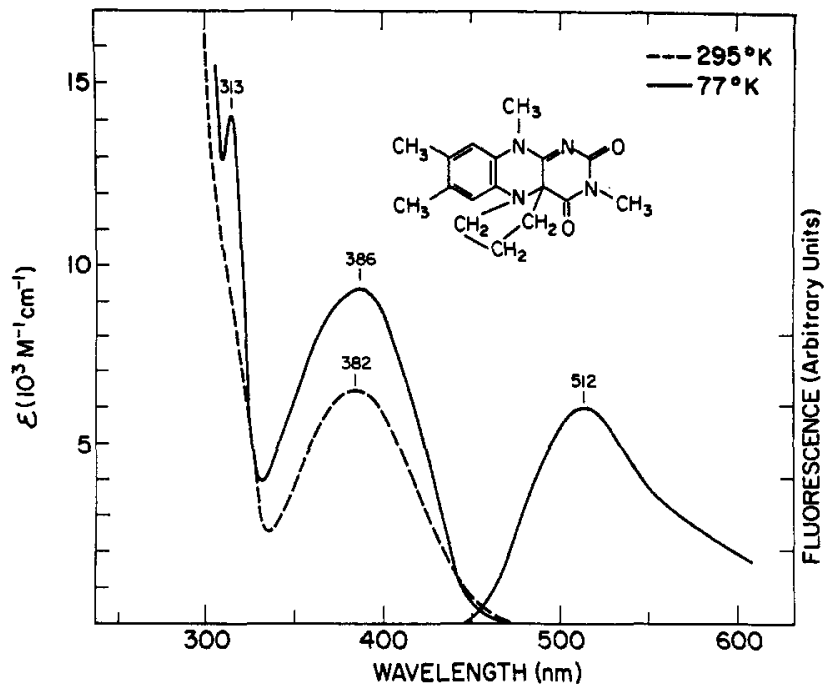

FIGURE 6: Absorption and fluorescence spectra of 4a,5-bridged $\mathrm{Fl}_{\text {red }}$ under the same conditions as described in Figures 3 and 5.

hibits a less-resolved absorption spectrum in the 300-nm region and a shift of the first band as compared to $C_{4 \mathrm{a}}$-ethoxy$N_{5}$-ethyl $F 1_{\text {red }}$ (Figure 5) at ambient temperature, but the same maximum at $\sim 380 \mathrm{~nm}$ as the latter model at $77^{\circ} \mathrm{K}$. However, with similar compounds in which the steric and electronic properties of the $\mathrm{C}_{4 a \mathrm{a}}$ and/or $\mathrm{N}_{5}$ substituent are varied sytematically a continuity in the absorption spectra of this series can be observed (Walker et al., 1970; Ghisla et al., 1973). Probably an interplay of steric interactions from the vicinal $\mathrm{C}_{4 \mathrm{a}}$ and $\mathrm{N}_{5}$ substituents (which would affect the planarity of the chromophore) and of electronic effects is responsible for the variations of the intensity and the shifts of these bands.

A peculiarity of reduced flavines is their ability to flex along their $\mathrm{N}_{10}-\mathrm{N}_{5}$ axis to form a butterfly-shaped molecule (Kierkegaard et al., 1971). In the normal reduced flavine the angle so formed between the two resulting planes in the molecule is probably small; with $\mathrm{N}_{1-}$ and $\mathrm{N}_{5}$-substituted reduced flavine models this angle has been shown by X-ray crystallography to be considerably larger $\left(20-35^{\circ}\right)$ (Kierkegaard et al., 1971). In connection with this, it has been pointed out that the degree of bending in these molecules is typically reflected by their absorption spectra (Hemmerich et al., 1971), where decrease of the 400-450- and the 290-300-nm absorption together with the appearance of a pronounced maximum in the $320-355-\mathrm{nm}$ region reflects a larger angle between the two planes of the molecule.

From the present work it appears that the low-energy absorption spectrum of reduced flavines consists of at least three transitions which may be assumed to correspond to $\pi \rightarrow \pi^{*}$ electronic excitations. These transitions, in particular the first one, are moderately forbidden, either because they are polarized in plane and along the short axis of the molecule or, alternatively, if they are long-axis polarized, because the folding of the flavine ring diminishes their probability. The planarity of the system may also affect the energy of the transitions. In the more planar compounds this should result in a red shift of the whole spectrum including the fluorescence. However, the substitution effects described above suggest that the first transition, also observed in the fluorescence, should be shortaxis polarized, corresponding mostly to charge transfer upon excitation from the electron-rich $\mathrm{C}_{4 \mathrm{a}}-\mathrm{N}_{5}$ region to the rest of the molecule. Then, as indicated by the results described 


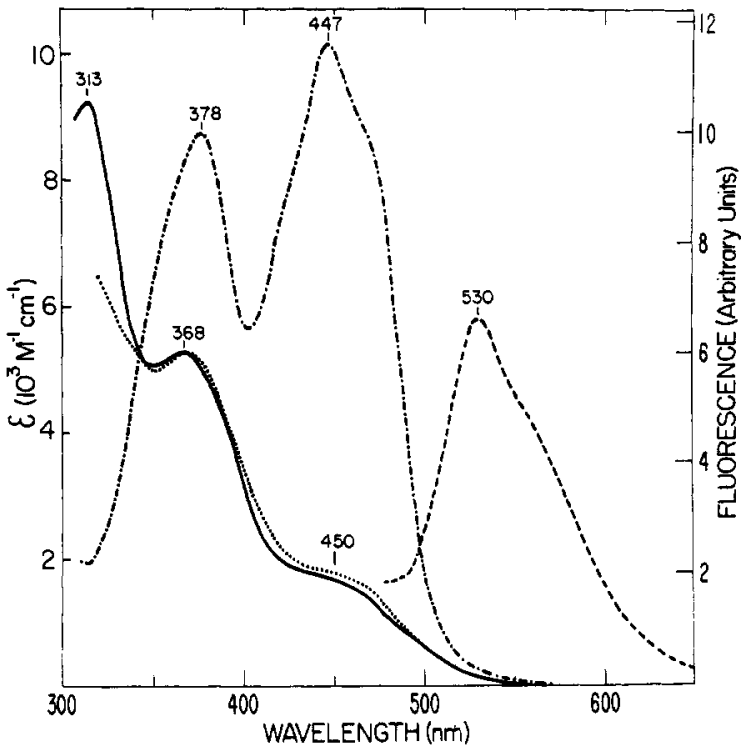

FIGURE 7: Absorption, fluorescence emission, and fluorescence excitation spectra of flavodoxin from $P$. elsdenit, $2 \times 10^{-5} \mathrm{M}$, in $0.1 \mathrm{M}$ pyrophosphate buffer $(\mathrm{pH} 8.5)$ at $25^{\circ}:(\cdot \cdots)$ absorption of the oxidized enzyme; ( - ) absorption spectrum of the enzyme reduced with 1 equiv of dithionite in the apparatus described by Foust $e t$ al. (1969); (---) fluorescence emission $\left(\lambda_{\text {exc }} 368 \mathrm{~nm}\right) ;(\cdots)$ fluorescence excitation spectrum $\left(\lambda_{\text {emiss }} 530 \mathrm{~nm}\right)$ of the reduced enzyme. The oxidized enzyme is devoid of fluorescence.

above, the substitution by electron donating groups at one of these atoms should increase the intensity of the transition.

On the other hand, it appears that the absence of fluorescence for most reduced flavines in fluid solvents and its relative intensity in glassy solvents at $77^{\circ} \mathrm{K}, \mathrm{N}_{1}-\mathrm{H}, \mathrm{N}_{5}-\mathrm{H}<\mathrm{N}_{1}-\mathrm{H}, \mathrm{N}_{5-}$ $R \ll C_{48}-R, N_{5}-R$, is also related to steric factors with the most efficient radiationless decay processes in the less rigid structures. Thus, both the rigidity of the molecule and that of its environment appear to govern the fluorescence yield. The mechanism of fluorescence quenching in the reduced flavines is probably quite different from that observed with $F 1_{\text {ox }}$ and its anion and cation, the latter being also fluorescent only in rigid media, where the dynamic proton quenching is minimized (Eley et al., 1970).

As a consequence of its peculiar configuration the free reduced flavine undergoes facile (vibrational) inversion processes of which the kinetic and thermodynamic parameters have been investigated (Tauscher et al., 1973). These vibration processes thus probably play an important role in the radiationless decay of the reduced flavine excited states. However, some of the inversion frequencies can be rather slow even at room temperature (Tauscher et al., 1973), as compared to the lifetime of the first fluorescent excited state. It is probable that a "full inversion" of the molecule is not required for radiationless dissipation of energy.

Absorption Spectra of Reduced Flavoproteins. Table I represents a survey of the spectral and fluorescence properties of reduced flavoproteins and similar data for the oxidized flavoproteins for comparative purposes. The spectra of the different reduced flavoenzymes can all reasonably well be simulated by the spectra of the models discussed above, under appropriate conditions. Therefore the spectra of the reduced enzymes in Table I have been classified according to their closest similarity to one of the model systems displayed in Figures 1-5 in their neutral ( $\mathrm{n}$ ) or anionic (a) form at ambient temperature or at $77^{\circ} \mathrm{K}$ (lt) (low temperature).
As a general trend it is found that the absorption maxima of the protein-bound reduced coenzymes are slightly shifted to longer wavelengths $(5-25 \mathrm{~nm}, c f$. Table I) indicating a more planar structure as compared to the corresponding free reduced flavines, and that the resolution of the bands is better. Likewise, a better resolution has been documented with oxidized flavoproteins (Palmer and Massey, 1968).

A major effect on the spectra of the flavine molecule is induced by changes in the ionization state as shown in Figures 1,2 , and 3. Free flavines such as FMN and FAD exhibit $\mathrm{p} K$ values between their neutral and anionic forms at $\sim 10$ (Walaas and Walaas, 1956) for the oxidized state, 8.5 for the semiquinone state (Ehrenberg et al., 1967), and $\sim 6.5$ for the fully reduced state (Lowe and Clark, 1956), which are reflected in their electronic spectra (Figure 1). For flavoproteins on the other hand, in most cases where information is available, no ionization has been observed over the limited $\mathrm{pH}$ region in which such enzymes are stable. Some exceptions are known; for example, in the oxidized state D-amino acid oxidase has a $\mathrm{p} K$ of 9.5 (Massey and Ganther, 1965) and glycolate oxidase a still lower $p K$ of 8.0 (Schuman and Massey, 1971). In the semiquinoid form, glucose oxidase (Massey and Palmer, 1966) and lysine monooxygenase (M. Flashner and V. Massey, unpublished results) are the only known cases to exhibit a $\mathrm{p} K$ close to that of the free coenzymes.

In the fully reduced state, only the flavodoxins have been examined in any detail, and in three such proteins a $\mathrm{p} K$ in the region 5.8-6.7 has been determined from the effects of $\mathrm{pH}$ on the redox potentials (Mayhew, 1971). This $\mathrm{p} K$ corresponds closely with a $\mathrm{p} K$ of the fully reduced $\mathrm{FMN}$; however, changes of $\mathrm{pH}$ in the range 8-5.4 have very little effect on the spectra. The reduced form of the flavodoxin from $P$. elsdenil, a typical example of this cluss, has an absorption with a distinct shoulder centered at $450 \mathrm{~nm}$ and two peaks in the near-ultraviolet, at 368 and $313 \mathrm{~nm}$ (Figure 7). Comparison with the models in Figures 2 and 3 and the fact that the fluorescence is shifted on these proteins $(\sim 500-510 \rightarrow 530 \mathrm{~nm})$ (Table I) by a similar amount as upon formation of the anion in the models (495 $\rightarrow 510 \mathrm{~nm}$ ) (Figure 3 ) suggest that in reduced flavodoxins the flavine is in its anionic form and has a rather planar conformation. A similar conclusion has been reached for the Shetna flavoprotein by Edmonson and Tollin (1971) on the basis of the $\mathrm{pH}$ dependence of reduction.

Within the reduced flavoproteins studied, many have absorption spectra with features similar to those of the neutral 1,5-dihydroflavine chromophore in an aprotic, unpolar solvent ( $c f$. Figure 2 and Table I). It should be pointed out that with most of these, e.g., p-hydroxybenzoate hydroxylase, melilotate hydroxylase, and D-amino acid oxidase, the shortest wavelength band is not well resolved from the uv absorption of the protein itself as it is in the case of flavodoxins. Of the other reduced flavoproteins examined, thioredoxin reductase is the only one which appears to have in its reduced form a spectrum which corresponds to that of the neutral 1,5-dihydroflavine chromophore in rigid medium, i.e., it has a twobanded spectrum with absorption maxima at 425 and 320 $\mathrm{nm}$, both peaks shifted about $20 \mathrm{~nm}$ to longer wavelengths than those seen with $\mathrm{F} 1_{\text {red }}$ at $77^{\circ} \mathrm{K}$ ( $c f$. Figure 3 ). In this case, the $\sim 350-\mathrm{nm}$ transition is probably hidden under the more intense third transition.

A distinctly different type of spectrum is exhibited by reduced lactate oxidase (Figure 8). Comparison with Figure 4 shows that this enzyme has spectral characteristics similar to the substituted models, i.e., it has very little absorbance in the $400-450-\mathrm{nm}$ region in contrast to normal reduced flavine 
(Figures 1-3) and has but a single absorbance peak maximal at $360 \mathrm{~nm}$. Furthermore, it differs significantly from the anion form of $F 1_{\text {red }}$ by lacking apparently completely the nearultraviolet band in the region of $300 \mathrm{~nm}$. These properties indicate that in this case the first and third transitions are probably blue shifted, as observed with the nonplanar models ( $c f$. Figure 4). Several reduced flavoproteins which have been characterized as 4 in Table I show essentially the same spectral features as lactate oxidase, viz. old yellow enzyme, glucose oxidase, and lipoyl dehydrogenase, but with the latter two enzymes the blue shift of the first transition is not so pronounced.

Fluorescence Properties of Reduced Flavoproteins. The emission of reduced lactate oxidase has been shown to be fluorescence by the observation that the emission lifetime is $<20 \mathrm{nsec}$. In view of the similarity of this emission with that observed with other reduced flavoproteins ( $c f$. below) and with model compounds ( $c f$. above), it is reasonable to assume that the emission has the same origin in all cases. A systematic study of the emission lifetimes of these reduced flavoproteins and compounds is planned.

Figure 8 shows the absorption and fluorescence spectra of lactate oxidase in its oxidized and reduced states as a typical example. While the oxidized enzyme is devoid of visible fluorescence, the reduced enzyme displays a relatively strong fluorescence emission, maximal at $507 \mathrm{~nm}$, with an intensity at its maximum $7 \%$ that of free FMN ( $c f$. Table I). That the emission observed from reduced lactate oxidase originates from the reduced flavine chromophore is shown by the good correspondence of the fluorescence excitation spectrum with that of the absorption spectrum (Figure 8). Addition of pyruvate under anaerobic conditions to reduced lactate oxidase results in the appearance of a long-wavelength absorption band, which has been attributed to formation of a chargetransfer complex between reduced enzyme and pyruvate (Lockridge et al., 1972). The dissociation constant for this complex has been estimated as $2 \times 10^{-3} \mathrm{M}$ from spectral titration studies (Lockridge et al., 1972). It is found that the addition of pyruvate results in a quenching of the fluorescence of the reduced enzyme, with almost complete quenching at very high pyruvate concentrations. From such fluorescence quenching experiments a $K_{d}$ of $1.5 \times 10^{-3} \mathrm{M}$ was obtained, in reasonable agreement with the value obtained from absorption spectrum changes. A similar quenching was observed on addition of lysine or ornithine to reduced lysine monooxygenase (M. S. Flashner and V. Massey, manuscript in preparation). These results support the interpretation of the longwavelength species being due to a molecular complex of the charge-transfer type; quenching of fluorescence in (chargetransfer) complexes in general and in complexes formed by oxidized flavine with a variety of molecules has been reported previously (Weber, 1950; Gibson et al., 1962).

While the majority of the flavoproteins tested did not show detectable fluorescence in their (unmodified) reduced state, in accord with the previous literature, a number did show significant emission. The maximum as well as the intensity of this fluorescence emission were found to vary considerably from flavoprotein to flavoprotein. The two most typical examples are represented by the reduced lactate oxidase (Figure 8) and by the reduced flavodoxins, e.g., from P. elsdenii (Figure 7) where the fluorescence emission maximum, while of low intensity, is shifted to $530 \mathrm{~nm}$. That the observed fluorescence was not due to incomplete reduction (i.e., that it was not due to oxidized flavine) was shown in all cases by the close correspondence of the fluorescence excitation spectrum with the

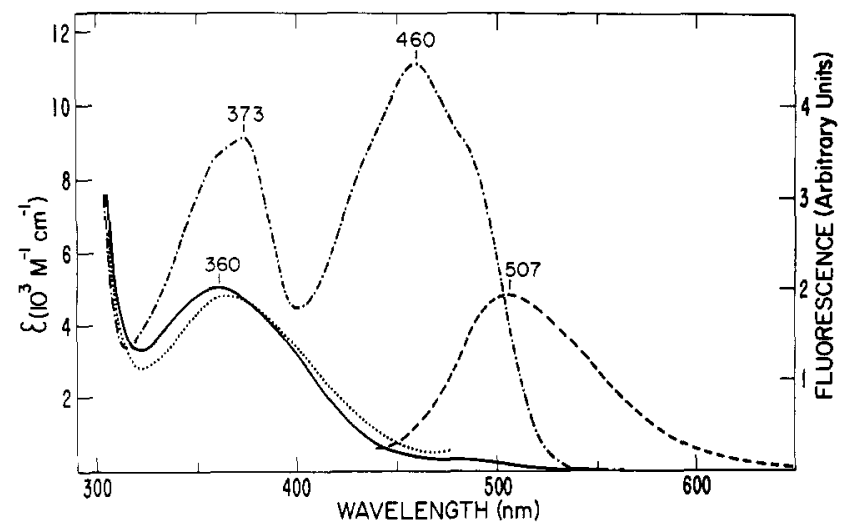

FIGURE 8: Absorption, fluorescence emission, and fluorescence excitation spectra of lactate oxidase, $3 \times 10^{-5} \mathrm{M}$ in $0.01 \mathrm{M}$ imidazole$\mathrm{HCl}$ buffer ( $\mathrm{pH} 7.0)$, at $25^{\circ}:(\cdot$.$) absorption spectrum of the$ oxidized enzyme; ( - ) absorption of the enzyme reduced with $\mathrm{L}$ lactate, after the decay of the initially formed, nonfluorescent complex ( $c f$. text for explanations); (.-.) fluorescence emission $\left(\lambda_{\text {exc }} 360\right.$ $\mathrm{nm}) ;(\cdots)$ fluorescence excitation spectrum $\left(\lambda_{\text {emiss }} 507 \mathrm{~nm}\right)$ of the reduced enzyme. The oxidized enzyme does not show detectable fluorescence.

absorption spectrum of the reduced enzyme. Furthermore, the spectra obtained were generally independent of the reducing agent used, e.g., substrate, dithionite, EDTA-light, or borohydride. An interesting relation is seen wherein those enzymes which exhibit fluorescence in the reduced state are for the most part nonfluorescent in the oxidized state and vice versa.

As the occurrence of fluorescence in many reduced flavoproteins cannot be correlated with known properties of the enzymes it is probable that it is affected by several factors which play an interdependent role. The fluorescence yield of $\mathrm{F} 1_{\text {ox }}$ has been shown to be quenched in model systems upon formation of complexes with various heteroaromatic, mostly electron-rich molecules as, e.g., tyrosine or tryptophan (Weber, 1950; Slifkin, 1971; Tollin, 1968). An analogous quenching is reported in this work for the complex formed by the reduced flavine of lactate oxidase and pyruvate. A strong quenching of the fluorescence has also been observed when sulfur-containing residues are covalently linked to the flavine nucleus (Ghisla and Hemmerich, 1971; Müller and Hemmerich, 1966). It is therefore reasonable to assume that the occurrence of fluorescence emission in (oxidized as well as reduced) flavoproteins is conditioned by the presence of specific amino acids close to the flavine binding site and also to the presence of specific (quenching) hydrogen bridges between protein and coenzyme. In agreement with this assumption a tryptophan and a methionine group in flavodoxin from Clostridium MP (Anderson et al., 1972; R. B. Burnett, G. D. Darling, D. L. Kendall, M. E. Lequesne, S. G. Mayhew, and M. L. Ludwig, private communication) and a tyrosine in flavodoxin from Desulfovibrio vulgaris (Watenpaugh et al., 1972) have been shown to be located in Van der Waals contact with the coenzyme by X-ray crystallography. It should be pointed out, however, that, due to the "opposite" chemical and electronic properties of $F 1_{\text {ox }}$ (electron deficient, acceptor) and $F 1_{\text {red }}$ (electron rich, donor), different interactions should be expected at the two oxidation levels. Thus, compounds which quench the $F 1_{o x}$ fluorescence by formation of complexes possibly do not affect the quantum yield of $F 1_{\text {red }}$ and vice versa.

On the other hand the results obtained in the model system and in particular at $77^{\circ} \mathrm{K}$ clearly suggest that the main factor leading to appearance of fluorescence in reduced flavoproteins 


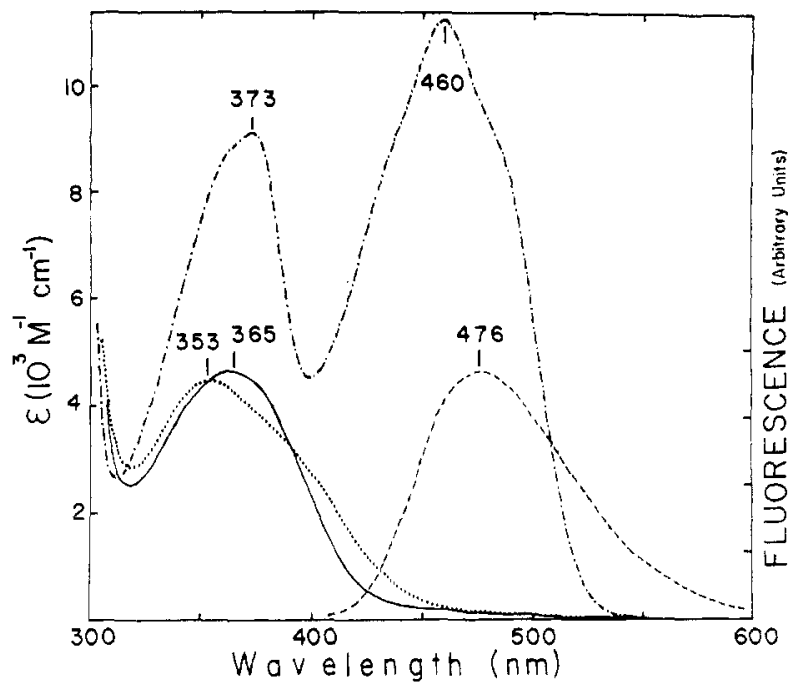

FIGURE 9: Absorption and fluorescence spectra of lactate oxidase and of its reduced $\mathrm{N}_{3} \mathrm{CH}_{2} \mathrm{COOH}$ derivative: $8 \times 10^{-5} \mathrm{M}$ in $0.01 \mathrm{M}$ imidazole- $\mathrm{HCl}$ buffer $(\mathrm{pH} 7)$, at $25^{\circ}:(-.$.$) absorption spectrum of$ the oxidized enzyme; $(.$.$) absorption spectrum of the enzyme re-$ duced with lactate ( $c f$. Figure 8) after addition of $10^{-2} \mathrm{M} \mathrm{BrCH}_{2}$ $\mathrm{COOH} ;(-)$ absorption and (---) fluorescence emission of the covalent $\mathrm{N}_{2} \mathrm{CH}_{2} \mathrm{COOH}$ adduct. This adduct was formed by irradiation of the reduced enzyme in the presence of bromoacetate with light in a way similar to that described by Walker et al. (1970).

is the rigidity introduced by the protein frame. Thus, it is reasonable to conclude that such a "freezing" of the vibrational inversion processes mentioned above occurs at least in those flavoproteins which show a fluorescence in the reduced state ( $c f$. Table I). In many flavoproteins, as, e.g., thioredoxin reductase (Table I; Zanetti and Williams, 1967) which have spectra indicating extensive restriction of mobility, a fluorescence emission should be expected. Probably in such cases of potentially fluorescent reduced flavoproteins the emission is quenched by other factors, e.g., interactions with specific protein residues as mentioned above or by dynamic quenching through molecules of the solvent $\left(\mathrm{H}^{+}\right)$which may retain free access to the coenzyme binding site.

Another line of evidence which provides support for the interpretation made above is the fact that substitution in the reduced flavoproteins leads to a strong increase in the fluorescence emission intensity in a similar way as observed with the models. The most illustrative example is provided by reduced lactate oxidase. When bromoacetate is added, the absorption maximum of the normal reduced enzyme ( $c f$. Figure 4) is blue shifted to $353 \mathrm{~nm}$ (Figure 9) and the fluorescence quenched by $65 \%$. Upon formation of the covalent $\mathrm{N}_{5} \mathrm{CH}_{2} \mathrm{COOH}$ adduct (as described in the legend to Figure 9) the fluorescence emission maximum is blue shifted to 476 $\mathrm{nm}$ and increased 4.7-fold in intensity compared to the free reduced enzyme, and thus has a quantum yield of $\sim 85 \%$ that of free FMN. Furthermore, the spectral effects induced by this substitution are entirely consistent with the changes observed upon immobilization of the $\mathrm{N}_{5}$-substituted model at $77^{\circ} \mathrm{K}$ (Figure 4 ); they consist of a red shift and intensification of the $\sim 350-\mathrm{nm}$ band and a marked decrease of the absorption in the $390-450-\mathrm{nm}$ region. As with the model this would be attributed to a blue shift and intensification of the first transition also apparent in the blue shift of the fluorescence.

Similar fluorescence emissions have been obtained with other reduced covalent derivatives of lactate oxidase. Thus, the inactivated enzyme obtained in the "suicide" reaction of this enzyme with an acetylenic substrate, 2-hydroxy-3-butynoic acid (Walsh et al., 1972), exhibits a fluorescence with an intensity $26 \%$ that of free FMN. An equally significant situation applies with D-amino acid oxidase. In the reduced form this enzyme does not display detectable fluorescence. However, on introduction of the bulky benzyl residue at position $4 a$ or $N_{5}$ by photoalkylation with phenyl acetate by the method of Walker et al. (1970), fluorescence is displayed (cf. Table I). Preliminary results with photoalkylation of other flavoproteins indicate that this may be a fairly general phenomenon.

\section{Conclusions}

From the comparisons and studies described above it may be concluded that the polarity of the protein environment at the flavine binding site and the interactions between prosthetic group and protein vary considerably within different classes of flavoproteins. Specific hydrogen bridges and the constraint induced by the protein structure affecting in particular the planarity of the reduced coenzyme could explain the observed differences in the absorption spectra. In some cases, in particular with reduced lactate oxidase, the spectral and fluorescence characteristics discussed above indicate that the reduced coenzyme is probably immobilized in a nonplanar form. In other cases, e.g., with thioredoxin reductase, it appears that the reduced coenzyme shows similar characteristics as more planar models in a rigid environment.

Finally we wish to emphasize, that contrary to commonly held beliefs, the reduced flavine chromophore is intrinsically fluorescent. In the case of free reduced flavines in solution, this fluorescence is not displayed, presumably because of energy dissipation to the environment, e.g., through the vibration processes described by Tauscher et al. (1973) and discussed above. This concept is in full accord with the reappearance of fluorescence emission from reduced flavines in rigid media at low temperature. In the case of reduced fluorescent flavoproteins the constraint introduced by the protein may hinder the same vibration processes thus reducing the radiationless decay to the extent that fluorescence emission reappears at room temperature.

Of particular interest is the apparent effect of ring substitution on the quantum yield of fluorescence. In view of the emphasis in the current literature on the possibility of covalent intermediates in flavoprotein catalysis, this work suggests that observation of fluorescence characteristics in partial reactions of flavoenzymes with their substrates may yield valuable information on the validity of these hypotheses.

\section{Acknowledgment}

We wish to thank Dr. M. S. Flashner for the data on lysine monooxygenase and for many helpful discussions and to Dr. J. D. Shore for help in the measurement of the fluorescence lifetime.

\section{References}

Anderson, R. D., Apgar, P. A., Burnett, R. M., Darling, G. C., LeQuesne, M. E., Mayhew, S. G., and Ludwig, M. L. (1972), Proc. Nat. Acad.Sci. U.S. 69, 3189.

Becker, W., and Pfeil, E. (1966), Biochem. Z. 346, 301.

Brumby, P. E., and Massey, V. (1968), Biochem. Prep. 12, 29.

Casola, L., Brumby, P. E., and Massey, V. (1966), J. Biol. Chem. 241, 4977.

Edmonson, D., and Tollin, G. (1971), Biochemistry 10, 133. 
Ehrenberg, A., Müller, F., and Hemmerich, P. (1967), Eur.J. Biochem. 21, 286.

Eley, M., Lhoste, J. M., Lee, C. Y., Cormier, M. J., and Hemmerich, P. (1970), Biochemistry 9, 2902.

Engel, P. C., and Massey, V. (1971), Biochem.J. 125, 879.

Foust, G. P., Burleigh, B. D., Mayhew, S. G., Williams, C. H., Jr., and Massey, V. (1969), Anal. Biochem. 27, 530.

Frisell, W. R., Chung, C. W., and Mackenzie, C. G. (1959), J. Biol. Chem. 234, 1297.

Ghisla, S., Hartmann, U., Hemmerich, P., and Müller, F. (1973), Justus Leibigs Ann. Chem., 1388.

Ghisla, S., and Hemmerich, P. (1971), FEBS (Fed. Eur. Biochem. Soc.) Lett. 16, 229.

Gibson, Q. H., Massey, V., and Atherton, N. M. (1962), Biochem. J. 85, 369.

Hamilton, G. A. (1971), Progr. Bioorg. Chem. 1, 83.

Hemmerich, P. (1964), Helv. Chim. Acta 47, 464.

Hemmerich, P., Ghisla, S., Hartmann, U., and Müller, F. (1971), in Flavins and Flavoproteins, Kamin, H., Ed., Baltimore, Md., University Park Press, pp 83-105.

Hemmerich, P., Massey, V., and Weber, G. (1967), Nature (London) 213, 728.

Howell, L. G., Spector, T., and Massey, V. (1972), J. Biol. Chem. 247, 4340.

Kierkegaard, P., Norrestam, R., Werner, P., Csoeregh, I., Glehn, M., Karlsson, R., Leijonmark, M., Roennquist, O., Stensland, B., Tillberg, O., and Torbjoersson, L. (1971), in Flavins and Flavoproteins, Kamin, H., Ed., Baltimore, Md., University Park Press, pp 1-22.

Kotaki, A., Maoi, M., Okuda, J., and Yagi, K. (1967), J. Biochem. (Tokyo) 61, 404.

Koziol, J. (1969), Photochem. Photobiol. 9, 45.

Lockridge, O., Massey, V., and Sullivan, P. A. (1972), J. Biol. Chem. 247, 8097.

Lowe, H. J., and Clark, W. M. (1956), J. Biol. Chem. 221, 983.

Main, L., Kasparek, G. J., and Bruice, T. C. (1972), Biochemistry 11, 3991.

Massey, V. (1966), Methods Enzymol. 9, 272.

Massey, V., Curti, B., Müller, F., and Mayhew, S. G. (1968), J. Biol. Chem. 243, 1329.

Massey, V., and Ganther, H. (1965), Biochemistry 4, 1161.

Massey, V., Müller, F., Feldberg, R., Schuman, M., Sullivan, P., Howell, L. G., Mayhew, S. G., Matthews, R. G., and Foust, G. P. (1969), J. Biol. Chem. 244, 3999.

Massey, V., and Palmer, G. (1966), Biochemistry 5, 3181.

Massey, V., and Swoboda, B. E. P. (1963), Biochem. Z. 338, 474.

Massey, V., and Williams, C. H., Jr. (1965), J. Biol. Chem. 240,4470 .
Matthews, R. G., and Massey, V. (1969), J. Biol. Chem. 244, 1779.

Mayhew, S. G. (1971), Biochim. Biophys. Acta 235, 276.

Mayhew, S. G., Foust, G. P., and Massey, V. (1969), J. Biol. Chem. 244, 803.

Müller, F., and Hemmerich, P. (1966), Helv. Chim. Acta 49, 2352.

Palmer, G., and Massey, V. (1968), in Biological Oxidations, Singer, T. P., Ed., New York, N. Y., Interscience, pp 263300.

Schuman, M., and Massey, V. (1971), Biochim. Biophys. Acta 227,500 .

Shethna, Y., Wilson, P. W., and Beinert, H. (1966), Biochim. Biophys. Acta 113, 225.

Slifkin, M. A. (1971), Charge Transfer Interactions of Biomolecules, New York, N. Y., Academic Press, pp 132-172.

Song, P. S. (1971), in Flavins and Flavoproteins, Kamin, H., Ed., Baltimore, Md., University Park Press, pp 37-61, and literature cited therein.

Strickland, S., and Massey, V. (1973), J. Biol. Chem. 248, 2944. Sun, M., Moore, T. A., and Song, P. S. (1972), J. Amer. Chem. Soc. 94, 1730.

Swoboda, B. E. P., and Massey, V. (1965), J. Biol. Chem. 240, 2209.

Takeda, H., Yamamoto, S., Kojima, Y., and Hayaishi, O. (1969), J. Biol. Chem. 244, 2935.

Tauscher, L., Ghisla, S., and Hemmerich, P. (1973), Helv. Chim. Acta 56, 630.

Tollin, G. (1968), in Molecular Associations in Biology, Pullman, B., Ed., New York, N. Y., Academic Press, pp 393-409.

Walaas, E., and Walaas, O. (1956), Acta Chem. Scand. 10, 122.

Walker, W. H., Hemmerich, P., and Massey, V. (1970), Eur.J. Biochem. 13, 258.

Walker, W. H., Singer, T. P., Ghisla, S., and Hemmerich, P. (1972), Eur. J. Biochem. 26, 279.

Walsh, C. T., Schonbrunn, A., and Abeles, R. H. (1971), J. Biol. Chem. 246, 6855.

Walsh, C. T., Schonbrunn, A., Babson, J., Lockridge, O., Massey, V., and Abeles, R. H. (1972), J. Biol. Chem. 247, 6004.

Watenpaugh, K. D., Sieker, L. C., Jensen, L. H., LeGall, J., and Dubourdieu, M. (1972), Proc. Nat. Acad. Sci. U. S. 69, 3185.

Weber, G. (1950), Biochem.J. 47, 114.

Wellner, O., and Meister, A. (1960), J. Biol. Chem. 235, 2013.

Zanetti, G., and Williams, C. H., Jr. (1967), J. Biol. Chem. 242,5232 . 